\title{
Enhancement the Corrosion Resistance of AISI 304 Stainless Steel by Nanocomposite Gelatin- Titanium Dioxide Coatings
}

Mohammed T. Hayajneh, Mohammed Almomani, Mohammad Al-Daraghmeh

Industrial Engineering Department, Faculty of Engineering, Jordan University of Science and Technology, P.O. Box 3030, Irbid, 22110, Jordan, E-mail: hayajneh@just.edu.jo,maalmomani7@just.edu.jo, mydaraghmeh9@just.edu.jo

\begin{abstract}
AISI 304 stainless steel is widely used in many industries due to its good properties such as corrosion resistance and mechanical properties. However, this steel is usually exposed to a severe environment that leads to high corrosion and mechanical failure. This study aims to examine the corrosion behavior of spin-coated AISI 304 stainless steel in a simulated marine environment contains $3.5 \mathrm{wt}$. \% $\mathrm{NaCl}$, by preparing and characterizing nanocomposite coatings with different weight fractions of $\mathrm{TiO}_{2}(0,1,2,3$ wt. \%) dispersed in a gelatin matrix. Three spinning speed sets (Low (L): 250-1000, Medium (M): 500-2500 and High (H): 750-4000) rpm were chosen to inspect the effect of spinning speed on the characteristics of coatings. Nanoparticles dispersed in gelatin matrix were examined by XRD, SEM, and EDX. The results approved the formation of crack-free and homogeneous coatings without any noticeable defect. Moreover, the corrosion evaluations were measured by potentiodynamic polarization technique. The results showed that compared to uncoated AISI 304 steel, the corrosion behavior of TiO $\mathrm{T}_{2}$ nanoparticles dispersed in gelatin matrix considerably improved the uniform and localized corrosion. The corrosion test results showed that increasing the spinning speed to a certain limit has a positive impact on the corrosion characteristics.
\end{abstract}

Keywords: Titanium Dioxide, Gelatin, Corrosion resistance, AISI 304 stainless steel, Nanocomposite coating.

\section{Introduction}

AISI 304 steel is extensively used in several applications due to its good properties such as corrosion resistance, mechanical strength and ductility [1]. It is mainly used in various industrial and household applications, especially food-handling equipment and machinery parts [2]. However, this steel is usually exposed to a severe environment that leads to high corrosion and mechanical breakdown [1]. Therefore, surface treatment is essential to enhance its properties against severe corrosion environments. Some surface amendment methods have been established to enhance the corrosion resistance and mechanical properties of AISI 304 steel without modifying its properties. These methods can be applied either by grains refinement [3] or by addition of alloying elements to the surface [4-5] or by covering the surface with protective layers [6-7].

Titanium dioxide is one of the most used ceramic oxides in many industrial applications because it has a very wide range of uses in the literature due it is unique characteristics. Since titanium dioxide has a very high refractive index, chemical stability, and nontoxicity; it is widely used in solar cells applications [8]. Titanium dioxide $\left(\mathrm{TiO}_{2}\right)$ is also commonly used in the literature as a coating material for enhancing the wear and corrosion resistance for various materials; AISI 304 stainless steel [9], AISI 3016L stainless steel [10], Magnesium alloy [11], Titanium alloy [12] and by many coating techniques; sol-gel dip-coating [10], plasma electrolytic oxidation [12], Electrodeposition [11]. Curkovic et al. [13] investigated the nanostructured titanium dioxide-coated AISI 304 steel corrosion resistance in the marine environment $(3$ wt. $\%$ of $\mathrm{NaCl}$ ) by a sol-gel dip-coating method and found that the number of $\mathrm{TiO}_{2}$ layers is a function of the corrosion resistance of the coated AISI 304. Fallet et al. [14] investigated the corrosion resistance, the electrochemical characteristics of titanium dioxide and hybrid $\mathrm{TiO}_{2}-\mathrm{SiO}_{2}$ powders on medium carbon steel by the sol-gel spin coating method in simulated $3.5 \mathrm{wt}$. $\%$ of $\mathrm{NaCl}$ solution. The study showed that the $\mathrm{TiO}_{2}$ coating alone beats the hybrid $\mathrm{TiO}_{2}-\mathrm{SiO}_{2}$ coating in corrosion resistance. Ghasemi et al. [15] discussed the heat treatment temperature effect on electrochemical behavior of hybrid titanium dioxide-ceria sol-gel by spin coating method on AISI 316L steel, the heat treatment temperature ranged between $300^{\circ} \mathrm{C}$ and $500^{\circ} \mathrm{C}$, they reported a corrosion resistance enhancement and a higher pitting resistance of the AISI 316L steel.

Gelatin is a natural polymer derived from collagen through an acid (type A-gelatin) or alkali (type B-gelatin) hydrolysis [16]. Gelatin has many characteristics such as, good adhesiveness and moderately low cost in addition to it has good bio properties which make it a good choice for medical applications, such as tissue engineering applications [17], pharmaceutical applications [18], and food and cosmetics products [19]. Recently, gelatin becomes a promising coating material on metal substrates for implants [20], although few researchers used gelatin as a gel matrix for nanocomposite powder dispersion instead of the old and traditional sol-gel method [16].

The aim of this study is to examine the corrosion behaviour of the unique gelatin-spin coated AISI 304 stainless steel in simulated severe corrosion environment containing chloride ion. The protection against corrosion of selected nano-ceramic titanium dioxide $\left(\mathrm{TiO}_{2}\right)$ powder at different titanium dioxide $\left(\mathrm{TiO}_{2}\right)$ weight percentages in gelatin were created by gelatin-spin coating process with different spinning speed sets will be investigated in a 3.5 wt. $\% \mathrm{NaCl}$ water solution using electrochemical analysis techniques.

\section{Materials and experimental methods}

\subsection{Substrates preparation}

In this research, the 304 stainless steel specimens were machined into $55 \mathrm{~mm} \times 55 \mathrm{~mm} \times 1 \mathrm{~mm}$ samples 
were used as substrates. Before coating, the AISI 304 substrates were immersed in a solution consisting of $\mathrm{HNO}_{3}$ and hydrogen $\mathrm{H}_{2} \mathrm{O}_{2}$ at 30:70 ratio of $\mathrm{H}_{2} \mathrm{O}_{2}: \mathrm{HNO}_{3}$ for 30 seconds to enhance the adhesion of gel coating to the AISI 304 substrates. Then the substrates were cleaned in Acetone for 15 minutes with the ultrasonic cleaner to remove any tightly adhering contamination on the substrate surface such as dust, dirt or any potential oil or grease that may be embedded onto the surface previously. Finally, the substrates were sonicated in deionized water for 15 min and dried by hot air stream before use.

\subsection{Preparation of gelatin- $\mathrm{TiO}_{2}$ coatings}

In order to prepare the coating material, various amounts of titanium dioxides nanoparticles (anatase, size of $10-25 \mathrm{~nm}$, purity $>99.0 \%$, density $3.9 \mathrm{~g} / \mathrm{cm} 3$, US Research Nanomaterials company) dispersed in gelatin at different wt. \%. Gelatin (type A porcine skin, $\mathrm{Mw}=50,000-$ 100,000 , Sigma) was selected as a standard 8 wt. \% gelatin in $20 \mathrm{wt} . \%$ acetic acid [16]. The solution was prepared at room temperature. After thorough gelatin dissolution, different weight percentages of $\mathrm{TiO}_{2}$ nanoparticles $(0,1$, 2 and 3) wt.\% were added to the solution. A magnet stirrer (Dragon Lab, MS-H-S) was used for at 24 hours room temperature to ensure homogeneous dispersion of $\mathrm{TiO}_{2}$ nanoparticles in the suspension. In order to stabilize the gelatin structure in water, crosslinking is essential. Ethyl3-(3-dimethylaminopropyl) carbodiimide (EDC, Sigma) was used as a crosslinking agent. 9 wt. \% EDC solutions in ethanol [16] was added to the suspension and magnetically stirred for 6 hours at $50^{\circ} \mathrm{C}$.

Spin-coating thin and homogeneous were generated with a spin-coating technique using a $\mathrm{KW}-4 \mathrm{~A}$ precision spin-coater (Chemat Technology Inc.) equipped with a vacuum pump (Gast Manufacturing). The spin coating process consisting of four main steps 1-placing a specific amount of the gel-like coating material in the middle of the sample with a needle; 2 -spinning the substrate at a certain low spinning speed (below $1000 \mathrm{rpm}$ ) in order to dispense the coating material regularly on the substrate outer flat surface, 3-spinning the substrate at a high spinning speed between (1000 to $10000 \mathrm{rpm}$ ) in order to accelerate the coating material to spread widely and uniformly on the substrate flat surface; and 4-drying the excessive gel-like material in order to obtain a dried and solidified thin coated layer on the outer surface of the substrate. In this research, three spinning speed sets (L, M, and $\mathrm{H}$ ) were chosen to study the effect of spinning speed on the characteristics of the coatings. Spinning time was chosen for all coated samples to be 15 seconds for the low coating speed and 30 seconds for the high coating speed. Full description of the procedure of preparing the gelatinnanoparticles coatings can be found in [21].

\subsection{Surface characterization}

The surface morphology and topography of the generated films were examined by SEM and EDX before the corrosion test to investigate the homogeneity and distribution of the nanoparticles within the gelatin matrix, and after the corrosion, to investigate the morphology of the coated samples. EDX was used for elemental analysis and chemical characterization of the substrate surface and corrosion products. The phase identification of coated samples was executed using XRD in order to check the presence of $\mathrm{TiO}_{2}$ nanoparticles within the film on the AISI 304 surface. In this study, direct current polarization (DCP) test was used to examine the characteristics of corrosion behavior of the coated AISI 304 samples. Gamry potentiostat Ref 600 corrosion testing instrument was used with graphite as a counter and saturated calomel as a reference electrode (SCE).

\section{Results and Discussion}

\subsection{Chemical characterization of $\mathrm{TiO}_{2}$ nanoparticles dispersed in the gelatin coating}

Figure 1a shows the uncoated AISI 304 steel surface before the corrosion test. It can be observed that the surface has a tube-shaped form that was created during the polishing process. Many scratch lines also can be seen as being parallel to the polishing lines. Figure $1 \mathrm{~b}$ shows SEM graphs of the pure gelatin-coated sample at medium (M) spinning speed set before the corrosion test. It can be seen that the surface is covered by a smooth and uniform gelatin layer without cracks or defects. Figure 1c shows SEM graphs of 2 wt.\% $\mathrm{TiO}_{2}$ nanocomposite coated sample at medium (M) spinning speed set before the corrosion test. The figure confirmed the distribution of $\mathrm{TiO}_{2}$ nanoparticles through the gelatin matrix uniformly and homogeneously without affecting the morphology of the gelatin matrix coating. Figures $1 \mathrm{~d}$ demonstrates EDX spectrum and quantitative analysis of coated AISI 304 steel with $\mathrm{TiO}_{2}$ nanoparticles dispersed in a gelatin matrix before the corrosion test. The figure reveals the presence of $\mathrm{TiO}_{2}$ nanoparticles in gelatin-coating before the corrosion test.

Figure 2 shows the uncoated AISI 304 surface morphology after corrosion testing. A salt brittle layer with many cracks that filled with the corrosion products had covered the whole surface. The cracks formation can be attributed to the internal stresses that were caused by the released gases during the cathodic reactions, or it can be formed as a result of the salt layer. It also can be seen from the figure that the uncoated AISI 304 steel surface had filled with many pits or cavities of different sizes. The gelatin coating layer without $\mathrm{TiO}_{2}$ nanoparticles was completely deteriorated and failed to protect the AISI 304 surface from corrosion as shown in Figure 3, while the distribution of $\mathrm{TiO}_{2}$ nanoparticles in gelation matrix enhance the performance of the gelatin coating in protecting AISI 304 steel after the corrosion test with only shallow cracks and pits as shown in Figure 4. Therefore, it is a sign of the stability and the functionality of the coatings. 


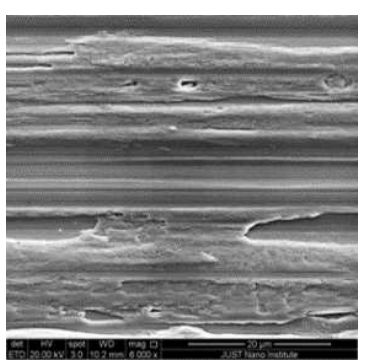

a

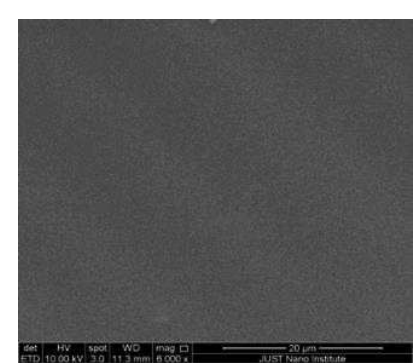

b

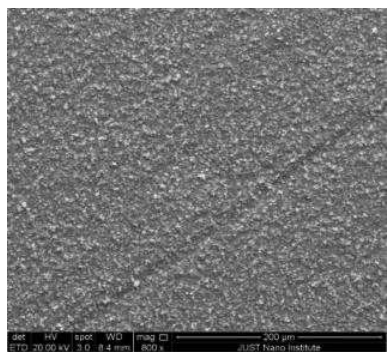

c

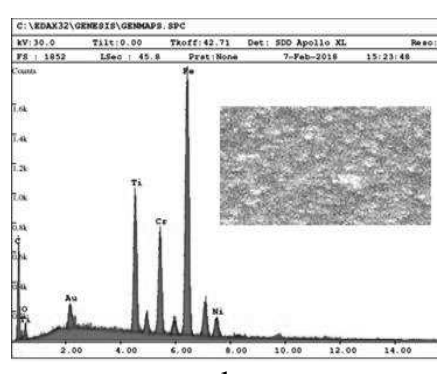

d

Fig. 1 The surface morphology of AISI 304 steel before corrosion test, (b) SEM graphs of pure gelatin-coated sample at medium spinning speed set before corrosion test, (c) SEM graphs of $2 \mathrm{wt}$. \% TiO $\mathrm{T}_{2}$ nanocomposite coated sample at medium spinning speed set before corrosion test, (d) EDX spectrum and quantitative analysis of coated AISI 304 steel with $\mathrm{TiO}_{2}$ nanoparticles dispersed in gelatin matrix before corrosion test
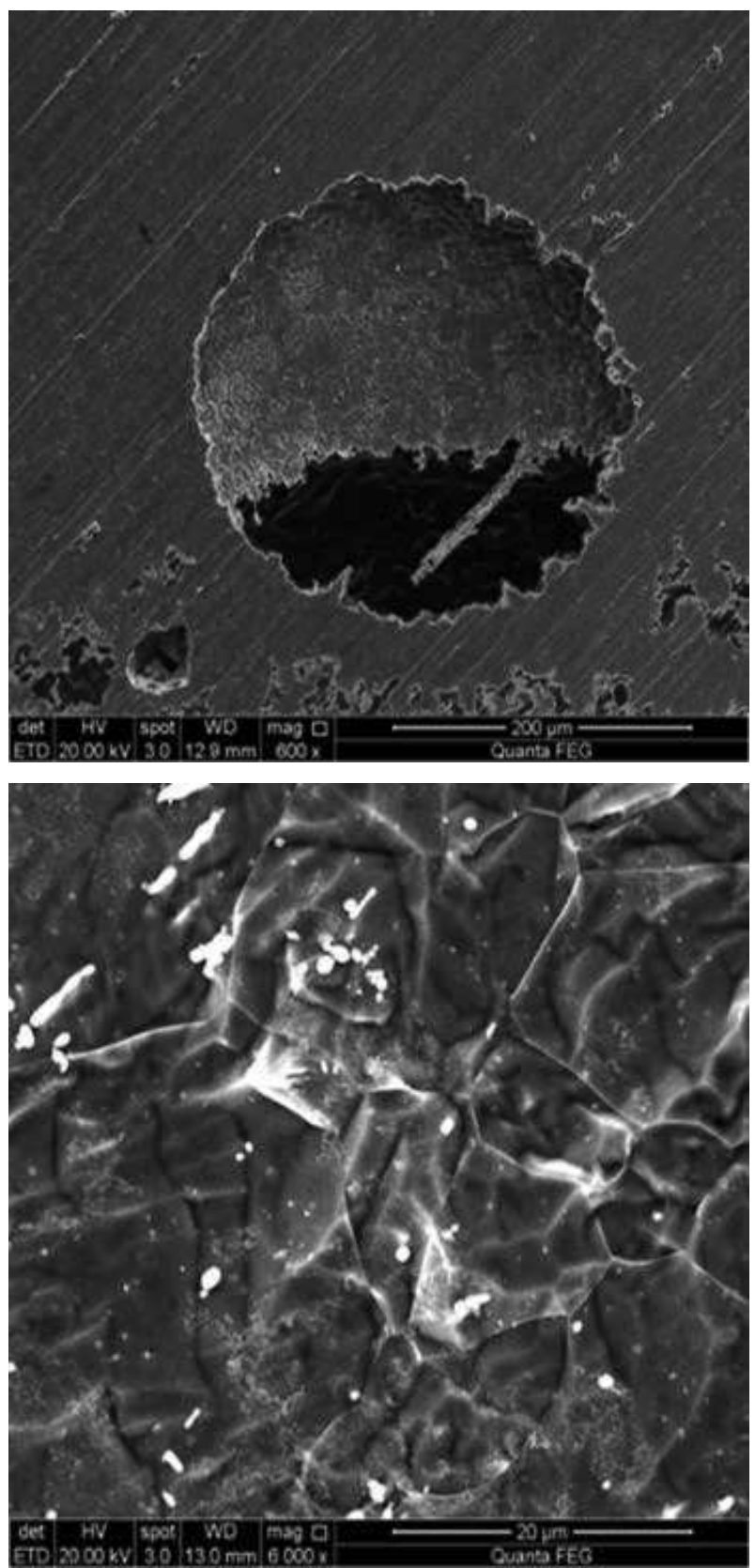

Fig. 2 The surface morphology of AISI 304 steel after the corrosion test.
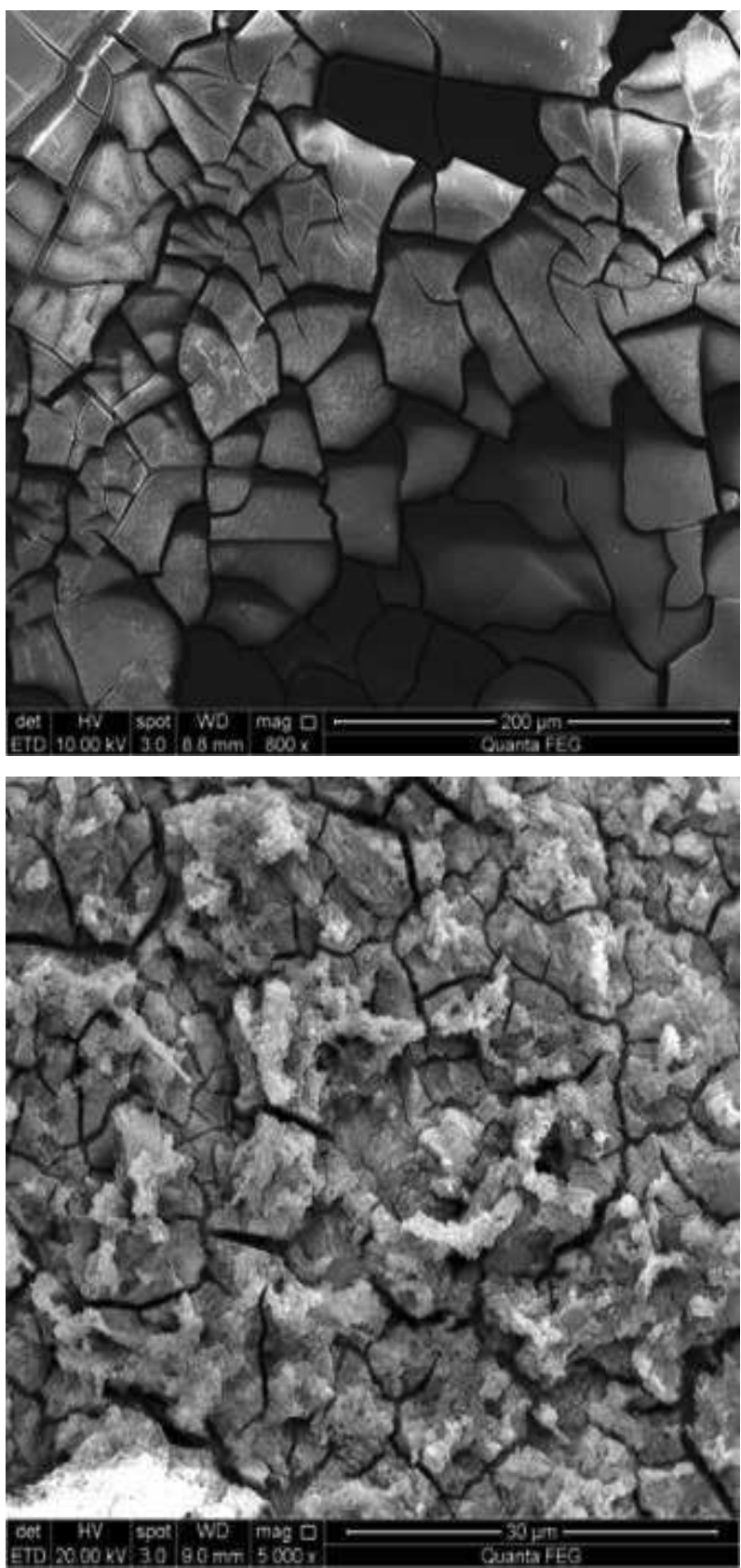

Fig. 3 SEM graphs of the pure gelatin-coated sample at the medium spinning speed set after corrosion test. 

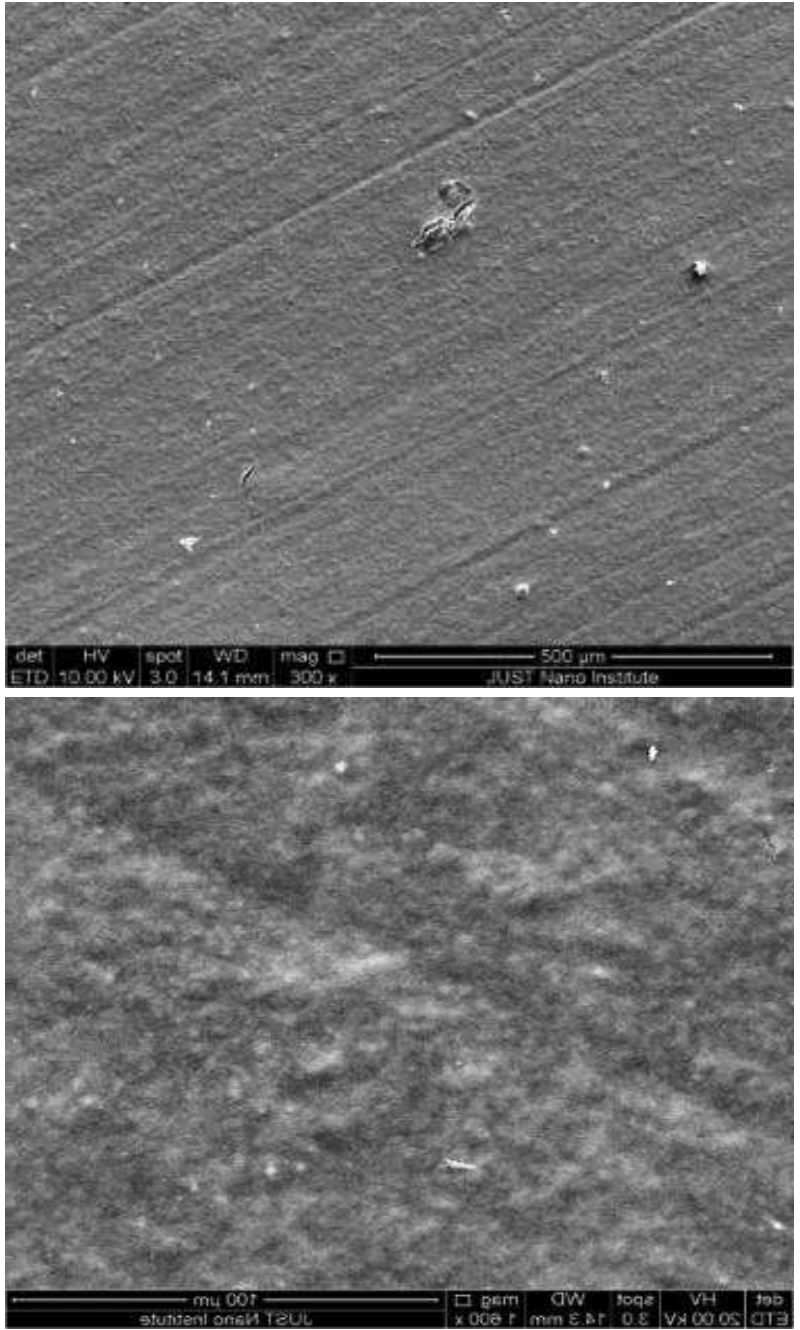

Fig. 4 SEM graphs of 2 wt. $\% \mathrm{TiO}_{2}$ nanocomposite coated sample at the medium spinning speed set after corrosion test.

\subsection{XRD analysis}

X-ray diffraction (XRD) analysis was used to confirm the presence of $\mathrm{TiO}_{2}$ nanoparticles within gelatin-coating as shown in Figure 5. It is shown that gelatin did not have any clear peak in XRD pattern, which is compatible with its amorphous nature, while XRD pattern of $2 \mathrm{wt} . \% \mathrm{TiO}_{2}$ nanoparticles dispersed in gelatin consisted of the main characteristic peaks of $\mathrm{TiO}_{2}$ at $2 \theta$ of $25^{\circ}, 25.209^{\circ}$, $37.059^{\circ}, 47.960{ }^{\circ} 53.069^{\circ}, 54.091^{\circ}, 62.79^{\circ}$, and $70.29^{\circ}$ indicating the presence of $\mathrm{TiO}_{2}$ nanoparticles in this coating, identification.

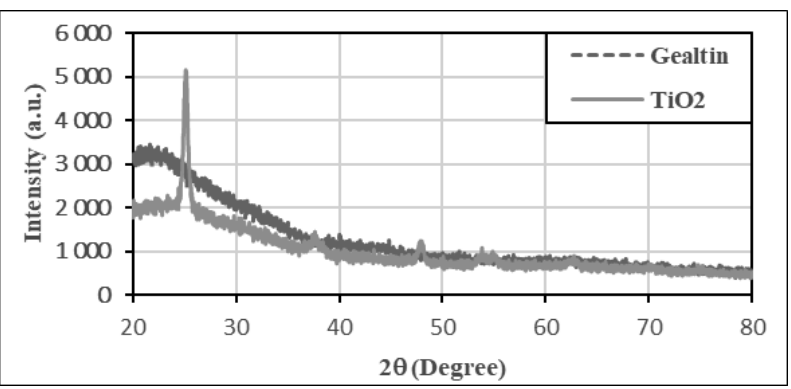

Fig. $5 \mathrm{XRD}$ pattern of gelatin and gelatin-TiO $\mathrm{O}_{2}$ on a fused glass substrate

\subsection{Electrochemical corrosion investigation}

Figure 6 shows the potentiodynamic polarization curves of AISI 304 steel spin-coated with nanocomposites coatings with different weight fractions $(0,1,2,3$ wt. \%) of $\mathrm{TiO}_{2}$ at low spinning speed set. It is shown that coating of AISI 304 steel with only gelatin does not cause any improvement in the corrosion rate. However, dispersing $\mathrm{TiO}_{2}$ nanoparticles in the gelatin matrix reduced the corrosion rate. The corrosion rate decreased significantly with 1 wt.\% $\mathrm{TiO}_{2}$ nanoparticles coating, because of the outstanding chemical stability, good thermal, electrical properties and low electron conductivity of $\mathrm{TiO}_{2}$, providing an excellent anticorrosion in addition to the gelatin barrier coating [22]. In contrast, increasing the weight fraction $\mathrm{TiO}_{2}$ nanoparticles increased the corrosion rate slightly as compared to $1 \mathrm{wt}$. \%. This result can be attributed to the tendency of increasing agglomeration of nanoparticles in gelatin as the weight fraction percentage of nanoparticles increased. Thus, increasing the coating surface roughness affects the corrosion rate adversely. Torkaman et al [16] found a similar behavior for the steel coated with forsterite in gelatin, where using $1 \mathrm{wt}$. \% forsterite nanopowder in gelatin matrix exhibited a better corrosion resistance as compared with steel coated with 3 wt. $\%$ forsterite nanocomposite coating.

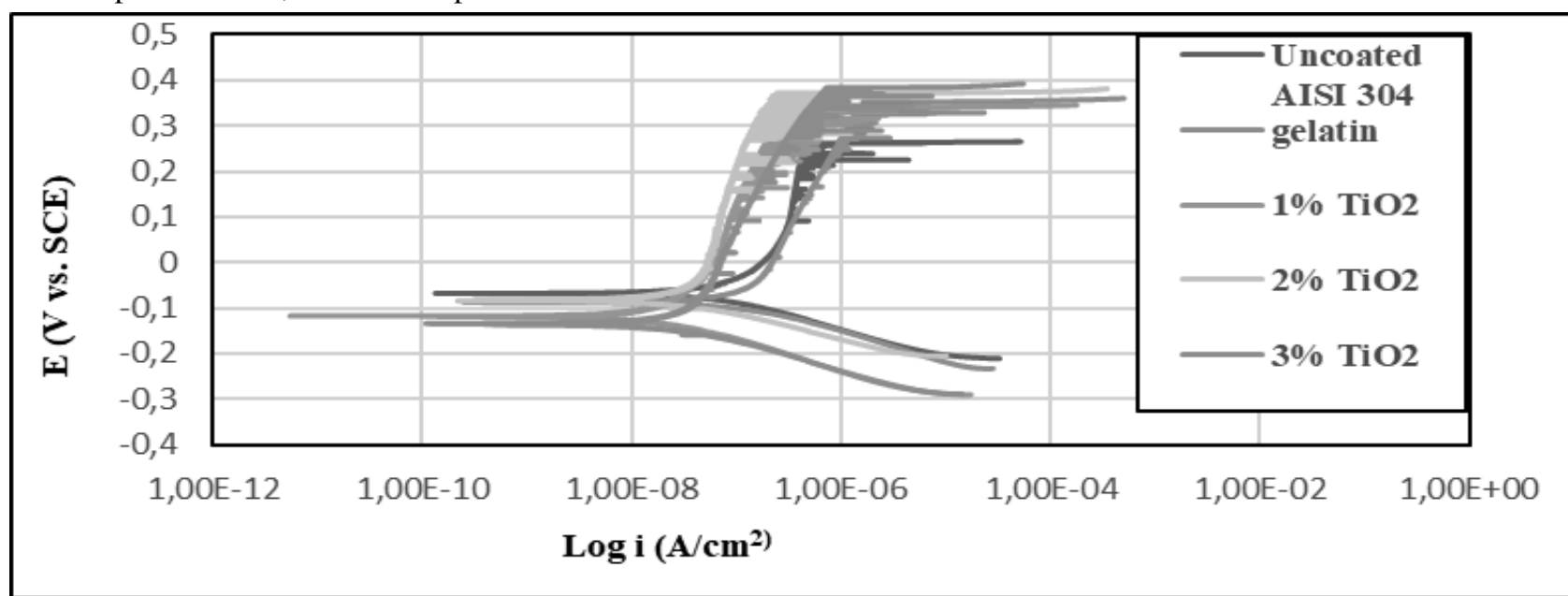

Fig. 6 The potentiodynamic polarization curves of AISI 304 steel coated with different nanocomposite coating at medium spinning speed set. 


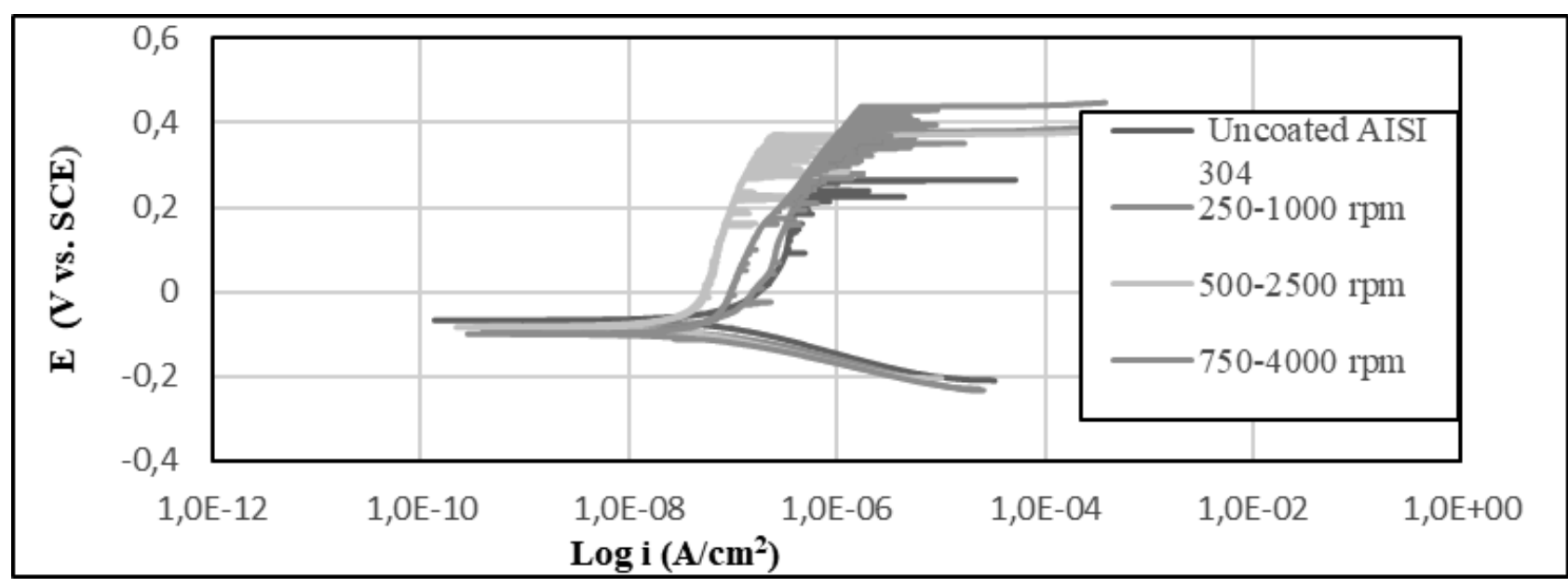

Fig. 7 The potentiodynamic polarization curves of AISI 304 steel coated with nanocomposite coating that contains $2 \%$ wt. of $\mathrm{TiO}_{2}$ dispersed in gelatin at different spinning speed set $(L, M$, and $H)$.

Figure 7 shows the potentiodynamic polarization curves of AISI 304 steel coated with 2 wt. $\%$ of $\mathrm{TiO}_{2}$ nanoparticles dispersed in a gelatin matrix at different spinning speed sets ( $\mathrm{L}, \mathrm{M}$, and $\mathrm{H}$ ) respectively. The use of low spinning speed caused a slight reduction of the corrosion rate; whereas increasing the spinning speed results in a greater enhancement of the corrosion resistance for the different examined weight fractions, since higher spinning speeds increased the centrifugal forces, which enhances the top coating surface smoothness [23], decreased the nanoscale roughness [24], and enhance the coating adhesion to the substrate [25].

Table 1 summarizes the corrosion rates, corrosion potentials $\left(\mathrm{E}_{\text {corr }}\right)$, corrosion current densities ( $\left.\mathrm{i}_{\text {corr }}\right)$ and critical pitting potentials $\left(\mathrm{E}_{\mathrm{pit}}\right)$ that were obtained from the Tafel scans for all examined samples. Three samples have been tested for each percentage of $\mathrm{TiO}_{2}$ nanoparticle at different spinning speeds. Chi-squared values were used to give information about the goodness of Tafel fit performed on the samples. The lower Chi-Squared value indicates that the performed fit is good. The fit is considered acceptable if the Chi-squared value is less than 100 [26]. It can be observed from the Table 1 that Icorr value can imply significant information about the corrosion behavior, it has a proportional relationship with the corrosion rate; the sample that has the least corrosion current density experienced the best corrosion resistance. In contrast to the Ecorr values that cannot give any specific information about the corrosion trend [27].

Figure 8 shows the effects of both spinning speed and weight fraction of dispersed $\mathrm{TiO}_{2}$ nanoparticles on the corrosion rate of AISI 304 steel. For comparison, the corrosion rate of uncoated AISI 304 steel is shown as a horizontal dashed line on the plot as a baseline. The results showed that coating at a medium spinning speed set (M) reduce the corrosion rate slightly compared to the coating at high spinning speed set $(\mathrm{H})$. Such a result can be attributed to the reduction in coating thickness with increasing the coating spinning speed [28]. Therefore, a tradeoff between coating spinning speed and coating thickness must be taken into account while choosing the appropriate spinning speed set.

Tab. 1 Corrosion rates and electrochemical constant values for the uncoated AISI 304 sample and AISI 304 coated with $\mathrm{TiO}_{2}$ dispersed in gelatin samples

\begin{tabular}{|c|c|c|c|c|c|c|}
\hline $\begin{array}{l}\text { The Examined } \\
\text { Samples }\end{array}$ & $\begin{array}{l}\text { Spinning } \\
\text { speed } \\
\text { Set } \\
(\mathrm{rpm})\end{array}$ & $\begin{array}{l}\text { Ecorr } \\
\text { (mV vs. } \\
\text { SCE) }\end{array}$ & $\begin{array}{l}\mathbf{i}_{\text {corr }} \\
\left(\mu \mathrm{A} / \mathrm{cm}^{2}\right)\end{array}$ & $\begin{array}{l}\text { Corrosion } \\
\text { rate } \\
\left(\mathbf{1 0}^{-3} \mathrm{mpy}\right)\end{array}$ & Chi-squared & $\begin{array}{l}\text { Epit } \\
\text { (V vs. } \\
\text { SCE) } \\
(\mathbf{m V})\end{array}$ \\
\hline $\begin{array}{l}\text { Uncoated AISI } 304 \\
\text { steel }\end{array}$ & - & -67.7 & 0.126 & 9.914 & 3.89 & 265 \\
\hline Gelatin only & L:250-1000 & -112 & 0.149 & 11.73 & 4.41 & 355 \\
\hline Gelatin only & M:500-2500 & -87 & 0.154 & 12.13 & 3.51 & 355 \\
\hline Gelatin only & $\mathrm{H}: 750-4000$ & -64.6 & 0.128 & 10.10 & 9.11 & 393 \\
\hline Gelatin- $\mathrm{TiO}_{2}-1$ wt. $\%$ & L:250-1000 & -43.8 & 0.077 & 6.09 & 7.84 & 350 \\
\hline Gelatin- $\mathrm{TiO}_{2}-1$ wt. $\%$ & M:500-2500 & -119 & 0.024 & 1.91 & 6.61 & 348 \\
\hline Gelatin- $\mathrm{TiO}_{2}-1$ wt. $\%$ & $\mathrm{H}: 750-4000$ & -143 & 0.040 & 3.18 & 4.34 & 384 \\
\hline Gelatin-TiO $2-2$ wt. $\%$ & L:250-1000 & -88.7 & 0.095 & 7.50 & 5.91 & 388 \\
\hline Gelatin- $\mathrm{TiO}_{2}-2$ wt. $\%$ & M:500-2500 & -156 & 0.055 & 4.28 & 3.88 & 418 \\
\hline Gelatin- $\mathrm{TiO}_{2}-2$ wt. $\%$ & $\mathrm{H}: 750-4000$ & -82.7 & 0.045 & 5.43 & 5.96 & 447 \\
\hline Gelatin- $\mathrm{TiO}_{2}-3$ wt. $\%$ & $\mathrm{~L}: 250-1000$ & -58.3 & 0.150 & 11.78 & 2.66 & 384 \\
\hline Gelatin- $\mathrm{TiO}_{2}-3$ wt. $\%$ & M:500-2500 & -135 & 0.041 & 3.21 & 4.76 & 385 \\
\hline Gelatin- $\mathrm{TiO}_{2}-3$ wt. $\%$ & $\mathrm{H}: 750-4000$ & -115 & 0.033 & 2.63 & 5.13 & 414 \\
\hline
\end{tabular}




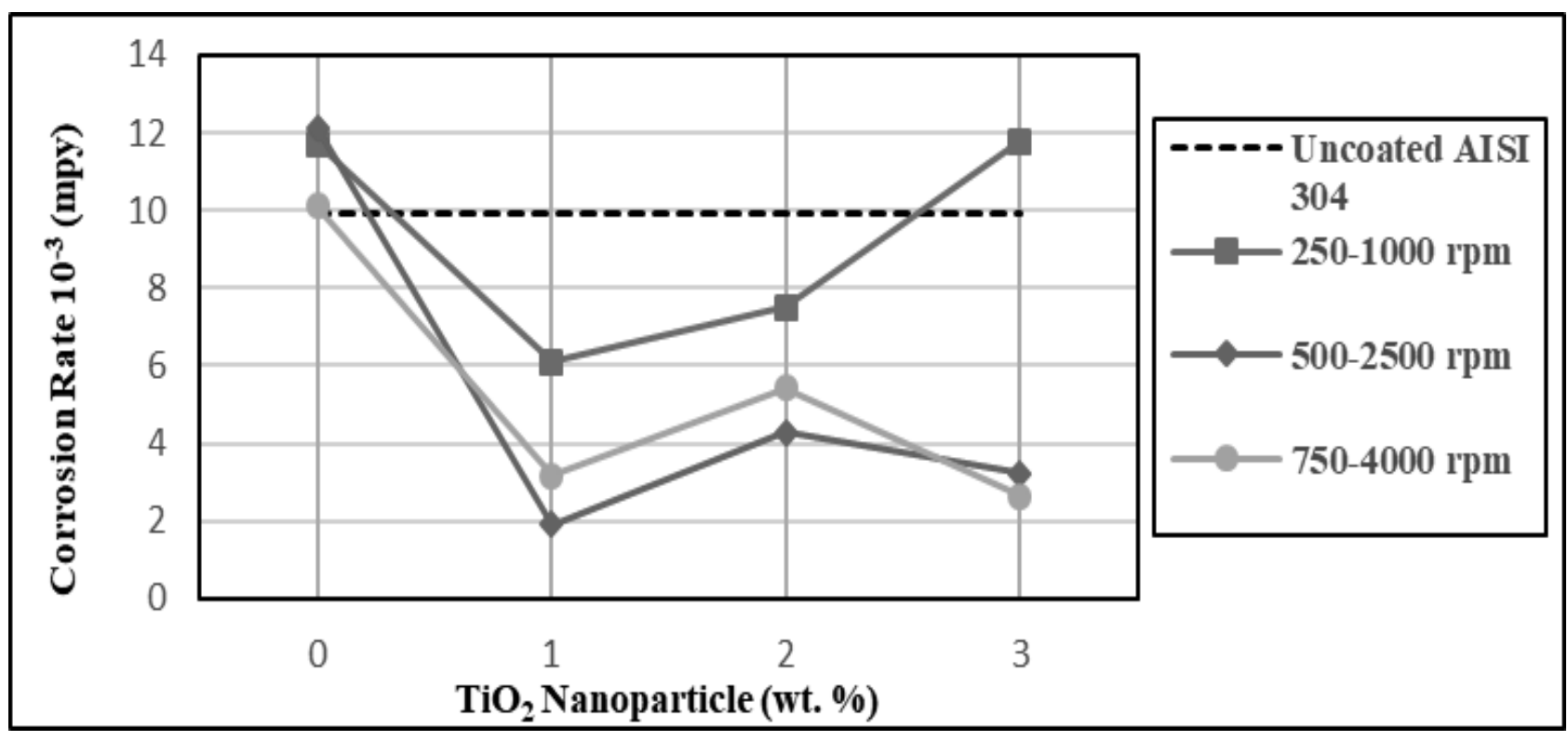

Fig. 8 Corrosion rate $\left(10^{-3} \mathrm{mpy}\right)$ of AISI 304 steel coated with different nanocomposite coatings at different spinning speed sets $(L, M$ and $H)$.

Figure 9 shows the effects of both weight fraction of dispersed $\mathrm{TiO}_{2}$ nanoparticles and spinning speed on the critical pitting potential behavior of AISI 304 steel coated samples. It is shown that the presence of $\mathrm{TiO}_{2}$ nanoparticles in the coating improves the critical pitting potential of the AISI 304 steel significantly. This behavior is due to the formation of the stable coating layers on AISI 304 steel surface compared to the unstable oxide film on the uncoated AISI 304 steel, which could not sufficiently protect against pitting corrosion[16]. At $2 \mathrm{wt} \% \mathrm{TiO}_{2}$, the critical pitting potential has been enhanced slightly compared to $1 \mathrm{wt} . \%$ and $3 \mathrm{wt}$. $\%$. Increasing the percentage of nanoparticles in gelatin increases the roughness of coating which increases the tendency of pits initiation. Therefore, there are a strong relationship between spinning speed and critical pitting potential where increasing the spinning speed increases the critical pitting potential significantly to a more positive values, because the higher spinning speed increases the centrifugal forces, which enhance the top coating surface smoothness [23], decrease the nanoscale roughness [24] and enhance the coating adhesion to the substrate [25]. The maximum improvements were obtained for the AISI 304 steel coated with 1 wt. $\%$ of $\mathrm{TiO}_{2}$ nanoparticles at the medium spinning speed set.

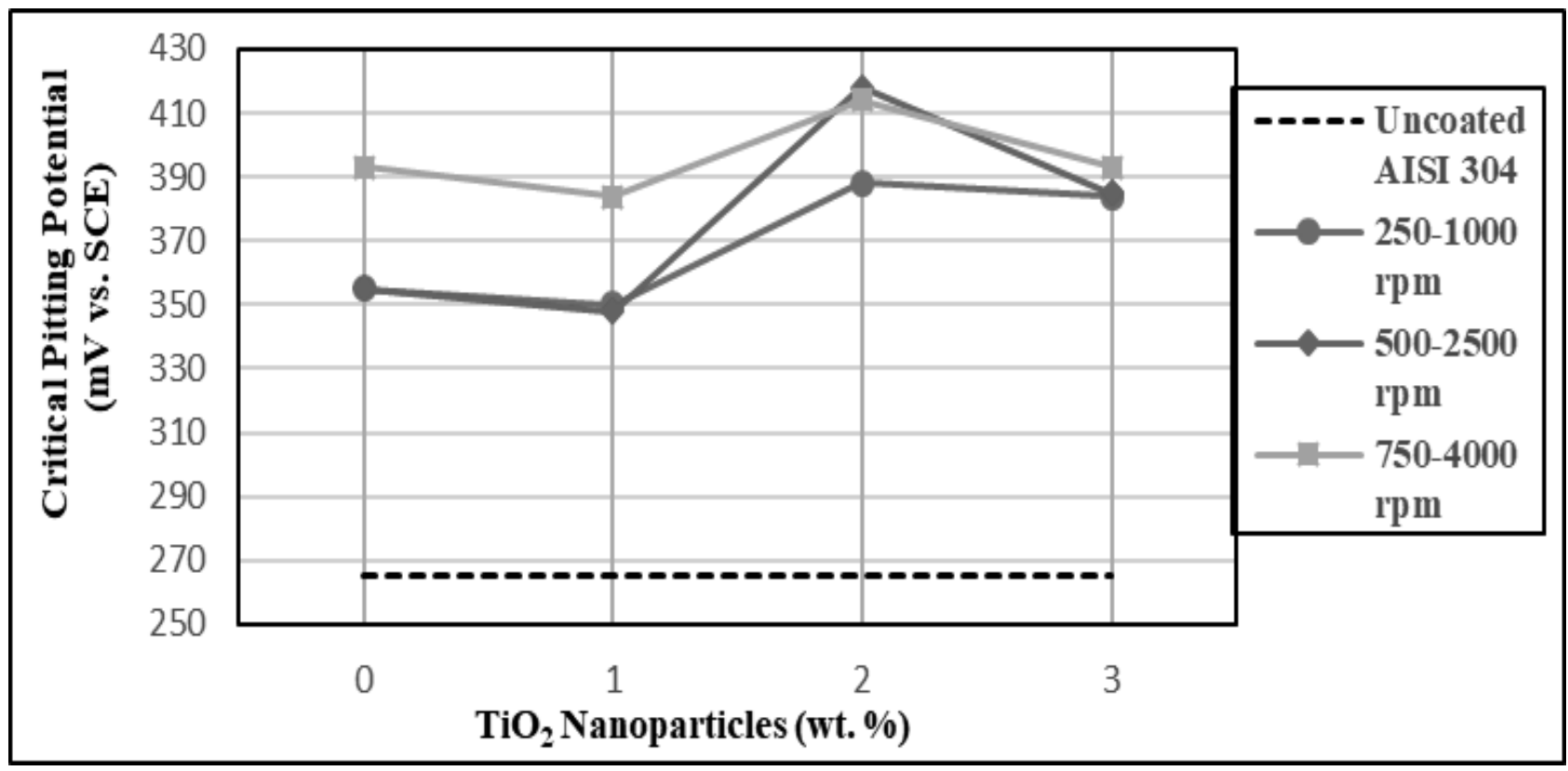

Fig. 9 Critical pitting potential ( $m V$ vs. SCE) of of AISI 304 steel coated with different nanocomposite coatings at different spinning speed sets $(L, M$ and $H)$. 


\section{Conclusions}

This This study examines the effect of applying $\mathrm{TiO}_{2-}$ gelatin-coating using the spin-coating technique on the corrosion characteristics of AISI 304 steel. Two factors were examined in this research on the corrosion behavior of AISI 304 steel: the percentage of $\mathrm{TiO}_{2}$ content and coating spinning speed. Based on the results of the study, the following can be concluded:

- Different nanocomposite coatings with different weight fractions of $\mathrm{TiO}_{2}(0,1,2,3$ wt. \%) dispersed in a gelatin matrix were well prepared on AISI 304 steel samples using spin coating technique at three different spinning speed sets.

- The uncoated AISI 304 steel exhibits the poorest corrosion resistance where cracks and pits appear after the potentiodynamic polarization tests.

- $\mathrm{TiO}_{2}$ content within the suspension has an observable impact on the corrosion resistance improvement. The nanocomposite coating of $1 \mathrm{wt} . \%$ $\mathrm{TiO}_{2}$ achieved the best results as compared to nanocomposite coatings that have 0,2 and $3 \mathrm{wt}$. $\% \mathrm{TiO}_{2}$.

- Coating at a medium spinning speed set reduces the corrosion rate slightly compared to the coating at low and high spinning speed sets. Therefore, a trade-off between coating spinning speed and coating thickness must be taken into account while choosing the appropriate spinning speed set.

\section{Acknowledgements}

This work was supported by a grant from the Deanship of Scientific Research at Jordan University of Science and Technology (JUST) with grant no. 39/2017. The authors would also like to acknowledge the engineering workshop employee of JUST for their help in completing this work.

\section{References}

[1] MAJUMDAR, J., MANNA, I. (1999). Laser surface alloying of aisi 304-stainless steel with molybdenum for improvement in pitting and erosioncorrosion resistance. In: Materials Science and Engineering A, Vol. 267, No. 1, pp.50-59.

[2] LUO, K., LU, J., ZHANG, Y., ZHOU, J., ZHANG, L., DAI, F., ZHANG, L., ZHONG, J., CUIA, C. (2011). Effects of laser shock processing on mechanical properties and micro-structure of ANSI 304 austenitic stainless steel. In: Materials Science and Engineering A, Vol. 528, No. (13-14), pp. 4783-4788.

[3] LU, J., LUO, K., ZHANG, Y., SUN, G., GU, Y., ZHOU, J., REN, X., ZHANG, X., ZHANG, X., ZHANG, L., ZHANG, L., CHEN, K., CUI, C.,
JIANG, Y., FENG, A., ZHANG, L. (2010). Grain refinement mechanism of multiple laser shock processing impacts on ANSI 304 stainless steel. In: Acta Materialia, Vol. 58, pp. 5354-5362.

[4] SUN, G., ZHANG, Y., ZHANG, M., ZHOU, R., WANG, K., LIU, C., LUO. K. (2014). Microstructure and corrosion characteristics of 304 stainless steel laser-alloyed with $\mathrm{Cr}-\mathrm{CrB} 2$. In: Applied Surface Science, Vol. 295, pp. 94-107.

[5] POKORNÝ, Z., DOBRÁCKY, D., STUDENÝ, Z. (2018) Influence of Chemical Composition on Layer Properties of Barrel Steels. In: Manufacturing Technology. Vol. 18, N. 6, pp.1007-1010.

[6] APARICIO, M., JITANU, A., RODRIGUEZ, G., DEGNAH, A., AL-MARZOKI, K., MOSA, J., KLEIN, L.C. (2015). Corrosion Protection of AISI 304 Stainless Steel with Melting Gel Coatings. In: Electrochimica Acta, Vol. 202, pp. 325-332.

[7] ZATKALÍKOVÁ, V., MARKOVIČOVÁ, L., LIPTÁKOVÁ, T., VAŠKO, A. (2017). Corrosion behavior of AISI 304 stainless steel in aggressive chloride environment. In: Manufacturing Technology. 17, 4, 639-643.

[8] SCHNEIDER, J., MATSUOKA, M., TAKEUCHI, M., ZHANG, J., HORIUCHI, Y., ANPO, M., BAHNEMANN, D. (2014). Understanding $\mathrm{TiO}_{2}$ photocatalysis: mechanisms and materials. In: Chemical Reviews, Vol.114, No. 19, pp. 9919-9986.

[9] KRISHNA, N., THINAHARAN, C., GEORGE, R., PARVATHAVARTHINI, N., MUDALI, U. (2015). Surface modification of type 304 stainless steel with duplex coatings for corrosion resistance in sea water environments. In: Surface Engineering, Vol. 3, No. 1, pp. 39-47.

[10] NAGHIBI, S., JAMSHIDI, A., TORABI, O., KAHRIZSANGI, R. (2013). application of taguchi method for characterization of corrosion behavior of $\mathrm{TiO}_{2}$ coating prepared by sol-gel dipping technique. In: Applied Ceramic Technology, Vol. 11, No. 5, pp. 901-910.

[11] CUI, L., QIN, P., HUANG, X., YIN, Z., ZENG, R., LI, S., HAN, E., WANG Z. (2017). Electrodeposition of $\mathrm{TiO} 2$ layer-by-layer assembled composite coating and silane treatment on $\mathrm{Mg}$ alloy for corrosion resistance. In: Surface and Coating Technology, Vol. 324, pp. 560-568.

[12] DZHURINSKIY, Z., GAO, Y., YEUNG, W., STRUMBAN, E., LESHCHINSKY, V., CHU, P., MATTHEWS, A., YEROKHIN, A., MAEV, R. (2015). Characterization and corrosion evaluation of $\mathrm{TiO}_{2}$ :n-HA coatings on titanium alloy formed by plasma electrolytic oxidation. In: Surface and Coatings Technology, Vol. 269, pp. 258-265.

[13] CURKOVIC, L., OTMACIC, H., SALOPEK, S., RENJO, M., SEGOTA, S. (2013). Enhancement 
of Corrosion Protection of AISI 304 Stainless Steel by Nanostructured Sol-Sel $\mathrm{TiO}_{2}$ Films. In: Corrosion Science, Vol. 77, pp. 167-184.

[14] FALLET, M., MAHDJOUB, H., GAUTIER, B., BAUER, J. (2001). Electrochemical behavior of ceramic sol-gel coatings on mild steel. In: Journal of Non-Crystalline Solids, Vol. 293-295, pp. 527533.

[15] GHASEMI, A., SHAHRABI, T., OSKUIE, A., HASANNEJAD, H., SANJABI, S. (2010). Effect of heat treatment on corrosion properties of sol-gel titania-ceria nanocomposite coating. In: Journal of Alloys and Compounds, Vol. 504, pp. 273-242.

[16] TORKAMAN, R., DARVISHI, S., JOKAR, M., KHARAZIHA, M., KARBASI, M. (2017). Electrochemical and in vitro bioactivity of nanocomposite gelatin-forsterite coatings on AISI 316 L stainless steel. In: Progress in Organic Coatings, Vol. 103, pp. 40-47.

[17] OLAD, A., AZHAR, F., (2014). The synergetic effect of bioactive ceramic and nanoclay on the properties of chitosan-gelatin/nanohydroxyapatite-montmorillonite scaffold for bone tissue engineering. In: Ceramics International, Vol. 40, No. 7, pp. 10061-10072.

[18] DJAGNY, K., WANG, Z., XU, S. (2001). Gelatin: a valuable protein for food and pharmaceutical industries: review. In: Critical Reviews in Food Science and Nutrition, Vol. 4, No. 6, pp. 481-492.

[19] KARIM, A., BAHAT, I. (2008). Gelatin alternatives for the food industry: recent developments, challenges and prospects. In: Trends in Food Science and Technology, Vol. 19, No. 12, pp. 644656.

[20] FRANTISKA, F., ESTHER, M., BEGONA, F. (2015). Electrophoretic deposition of gelatin/hydroxyapatite composite coatings onto a stainless steel substrate. In: Key Engineering Materials, Vol. 654, pp.195-199.

[21] ALMOMANI, M, HAYAJNEH, M, ALDARAGHMEH, M. (2019). The corrosion behavior of AISI 304 stainless steel spin coated with
ZrO2-gelatin nanolaminates. Materials Research Express. Volume 6, Number 9. pp. 0965c4

[22] WANG, D., BIERWAGEN, G. (2009). Sol-gel coatings on metals for corrosion protection. In: Progress in Organic Coatings, Vol. 64, No. 4, pp. 327-338.

[23] ZABIHI, F., XIE, Y., GAO, S., ESLAMIAN, M. (2015). Morphology, conductivity and wetting characteristics of pedot: pss thin films deposited by spin and spray coating. In: Applied Surface Science, Vol. 338, pp. 163-177.

[24] COJOCARIU, A., CATTOËN, X., PARC, R., MAURIN, D., BLANC, C., DIEUDONNÉ, P., BANTIGNIES, J., MAN, M., BARTLETT, J. (2016). Evaporation-induced self-structuring of organised silica nanohybrid films through cooperative physical and chemical interactions. In: Physical Chemistry Chemical Physics, Vol. 18, No.11, pp. 7946-7955.

[25] CHIANG, C., TSENG, Z., WU, C. (2014). Planar heterojunction perovskite/pc $71 \mathrm{bm}$ solar cells with enhanced open-circuit voltage via a (2/1)-step spin-coating process. In: Journal of Materials Chemistry A, Vol. 2, No. 38, pp.15897-15903.

[26] NOMANI, J., PRAMANIK, A., HILDITCH, T., LITTLEFAIR, G. (2015). Chip formation mechanism and machinability of wrought duplex stainless steel alloys. In: The International Journal of Advanced Manufacturing Technology, Vol. 80, No. (5-8), pp.1127-1135.

[27] LIM, C., LIM, C., GUPTA, M. (2003). Wear behaviour of SiCp-reinforced magnesium matrix composites. In: Wear, Vol. 255, No. (1-6), pp. 629-637.

[28] WILTSCHKA, O., BÖCKING, D., MILLER, L., BRENNER, R., SAHLGREN, C., LINDÉN, M. (2014). Preparation, characterization, and preliminary biocompatibility evaluation of particulate spin-coated mesoporous silica films. In: Microporous and Mesoporous Materials, Vol. 188, pp. 203-209. 